\title{
Pamuk Yaği Ve Atik Pamuk Yaği Biyodizelinin Bir Dizel Jeneratörde Yakit Olarak Kullaniminin Etkileri
}

\author{
${ }^{1 *}$ Hakan Karakaya and ${ }^{2}$ Selçuk Yağız \\ 1*Batman University Eng.-Arc. Fac. Mechanical Engineering Department hakan.karakaya@batman.edu.tr \\ ${ }^{2}$ Batman University Tec. Fac. Department of Automotive Engineering selcukyagiz21@gmail.com
}

\begin{abstract}
Özet
Günümüzde nüfusun artmasl ve dünya ekonomisinin büyümesine paralel olarak enerji ihtiyacı her geçen gün artmaktadır. Bununla beraber fosil yakıt kaynaklarının kısıtlı olmasl, fosil yakıt kaynaklarının çevre kirliliği üzerindeki olumsuz etkileri toplumları alternatif enerji kaynakları arayışına yöneltmiştir. Biyodizelin düşük emisyon profili, doğada çözünebilirliği ve toksik olmaması gibi özelliklerinden dolayı alternatif yakıt olarak kullanılmasını oldukça cazip hale getirmektedir. Bu çalışmada fosil yakıtlara alternatif olarak; transestrifikasyon yöntemi ile pamuk yağl ve atık pamuk yağından bir alkolün, katalizör eşliğinde reaksiyona girerek yăg asidi alkol esterleri ve gliserin oluşturmasıyla elde edilen biyodizelin dizel yakıt ile belirli oranlarda karıştırtlarak motor üzerinde yanma, performans ve egzoz emisyonlarının değişimi karşılaştırılmıştır. Alternatif yakıt deneylerinde motor referans dizel yakat ile test edilip elde edilen performans değerleri motorun alternatif yakat olarak kullanılacak biyodizel karışımı yakıtlar ile her bir yakıt karışımı için yapılan deney sonuçları dizel yakıt referans değerleri ile karşılaştırllip grafikler oluşturulmuştur. Sonuç olarak elde edilen biyodizelin motorlarda tek kullanılması motor üzerinde çeşitli sorunlar yaratabileceğinden dizel yakıt ile belirli oranlarda karıştırılarak kullanılabileceği sonucuna varılmıştır.
\end{abstract}

Anahtar Kelimeler: Biyodizel, pamuk yağı, transestrifikasyon, katalizör, dizel motor, alternatif yakıt

\section{Giriş}

Dünyada ve ülkemizde, önemli öğelerden biri olan enerjiye gün geçtikçe talep artması, bu duruma karşın dünyadaki enerji kaynaklarının sınırlı olması ve sürekli azalan yönde grafik göstermesi ülkeleri belirlenen enerji politikalarının tekrar gözden geçirilmesine itmiştir. Nüfusun artması, ekonomik kalkınma ve ideal yaşam standartlarına ulaşılma isteği enerji tüketimini arttırıcı yöndeki bazı etmenlerdir [1]. Dünyada tükenebilir enerji kaynaklarının sınırsızca kullanımı, sonuç olarak doğada kalıcı tahribatlara yol açması ve artan enerji fiyatları araştırmacıları; yenilenebilir ve temiz enerji kaynaklarına yöneltmiştir. Enerji talebinin karşılanmasında fosil kökenli rezervlere eğilimin artması çevresel sorunların artmasında ciddi bir boyut kazanmakta, fosil yakıtlar zararlı gazlar çevreyi kirletmekte, $\mathrm{CO}_{2}$, NOx salınımları sera etkisi yaparak iklim üzerinde geri dönülemez sonuçlar doğurarak dünyanın doğal dengesini

*Corresponding author: Address: Eng.-Arc. Fac. Mechanical Engineering Department Batman University, 72060, Batman TURKEY. E-mail address: hakan.karakaya@batman.edu.tr, Phone: +904882174115 
bozmaktadır. Küresel iklim değişiklikleri ile birlikte tüm canlı yaşamının sürmesi tehlikeye girmiştir [2]. Yapılan araştırmalar göz önünde bulundurularak dünyada fosil yakıt mevcut rezervlerinin kullanım süreleri petrolde, ortalama 41 yıl, doğal gazda 63 y1l, kömürde ise 218 y1l ömürlerinin olduğu düşünülüyor. [3]. Petrol ve kökenli ürünler hayatımızın birçok alanında kullanılmakla beraber, daha çok ulaşım sektöründe önemli bir yer edinmiştir [4]. Dizel motorlarında yakıtın türüne bağlı olarak egzoz emisyonlarında, bazı zararlı partiküllerde oluşmaktadır. Egzoz gazlarındaki bu zararlı partikülleri azaltmak için motor üretiminde tasarım ve üretim sırasında yanma öncesi, yanma anı ve yanma sonrasında olmak üzere farklı önlemler alınmaktadır. Bu önlemlerin dışında, farklı yakıtlar kullanarak da bu zararlı ürünlerin azaltılması yoluna gidilebilir. Fosil kökenli yakıtların sonlu olmasından dolayı, dizel motorlarında bitkisel yağ ile alternatif yakıt üretme çalışmaları devam etmektedir [5]. Biyodizelin, dizel motorları için bitkisel veya hayvansal yağlar gibi yenilenebilir kaynaklardan üretilebilen alternatif bir yakıt olduğunu, dizel motorlarında biyodizel kullanımının hem ekonomik hem de çevresel bakımdan büyük yararlar sağlayacağının düşünülmektedir [6].

Fukuda ve ark. tarafından yapılan, yağların transesterifikasyon ile biyodizel yakıt üretimine yönelik araştırma, normalde esterleşme için alkolün 3:1 molar oranda yeterli olacağ1 ancak esterleşmenin süresi ve oranının yüksek olması amacıyla soya, ayçiçeği, fıstık ve pamuk gibi bitkilerin yağları için 6:1 oranının çok daha verimli olacağı ve esterleşme oranının yükseleceği belirtilmektedir [7].

Yücesu vd. , çalışmalarında tek silindirli bir dizel motorunda alternatif yakıt olarak bitkisel yağ kullanımının motor performansı ve emisyonlarına etkisini incelemişlerdir. Yakıt olarak ayçiçek yağı, pamuk yağı, soya yağı ve bunlardan elde edilen metil esterlerini kullanmışlardır. Yapılan testler sonucunda bitkisel yağların motor performansı dizel yakıtına göre düşük, duman koyuluğu daha yüksek olduğunu ortaya çıkarmışlardır. Bitkisel yağlardan üretilen metil esterlerinin ise motor performanslarının dizel yakıtına yakın olduğunu ortaya koymuşlardır [8].

Çelik, biyodizel üretimi üzerine yaptığı çalışmada, yağ oranının az olmasına rağmen ekim alanının fazla olması nedeniyle, hammadde olarak rafine pamuk yağını ve transesterifikasyon yöntemini tercih etmiştir. Katalizör olarak 3,5 g/L,yağ oranında $\mathrm{NaOH}$, alkol olarak \% 20 L/L,yağ oranında metil alkol kullanmıştır. Reaksiyon sıcaklığını $65{ }^{\circ} \mathrm{C}$, süresini 60 min-1 tutmuştur. Transesterifikasyon yöntemi ile rafine pamuk yağından elde edilen ham biyodizel distile su ve deiyonize ile yıkamaya tabi tutmuştur. Pamuk yağı metil esterinin yakıt özelliklerinin, yıkama suyu olarak deiyonize suyun kullanılması durumunda daha iyi olduğunu belirtmiştir [9].

Karabektaş vd., pamuk yağı metil esterini ön 1sıtmaya tabi tutarak dizel motorunda kullanmışlardır. Pamuk yağı metil esterini yanma odasın girmeden önce 30, 40, 60 ve 90 oC ssıtarak motor performansındaki değişiklikleri incelemişlerdir. Buna göre en iyi sonucu $90{ }^{\circ} \mathrm{C}$ ön 1sıtmalı pamuk yağı biyodizelinden sağlandığı tespit etmiş̧lerdir [10].

Agarwal içten yanmalı motorlarda kullanılan biyo-yakıtların (etanol ve biyodizel) motor performansı ve emisyon değerleri üzerine yapılmış çalışmaları değerlendiren geniş kapsamlı bir çalışma yapmıştır. Çalışmasının biyodizel bölümünde, biyodizelin belirli oranlarda dizel yakıt ile karıştırılıp içten yanmalı motorlarda kullanıldığında motor performansında az da olsa düşüş olduğunu belirtmiştir. Emisyon değerlerinde ise $\mathrm{CO}, \mathrm{HC}$ ve partikül miktarlarında azalma olduğunu belirtmiştir. NOx miktarında ise yakıt içerisine biyodizel oranının artması ile ciddi bir artışın olduğunu özellikle vurgulamıştır [11].

Monyem and Gerpen, çalışmalarında, biyodizel yakıtların egzoz emisyon ve motor 
performansına etkilerini araştırmışlardır. John Deere 426 TDI Dizel motorda oksitlenmiş ve oksitlenmemiş biyodizel yakıt ile No-2 Dizel yakıtı kıyaslanarak motor performans ve emisyon değerleri belirlemeye çalışmışlardır. Araştırma sonuçlarına göre, oksitlenmiş ve oksitlenmemiş biyodizel yakıtının motor performansının 2 no'lu Dizel yakıtıyla neredeyse aynı olduğunu, biyodizel yakıtının daha düşük $\mathrm{CO}$ emisyona sahip olduğunu ayrıca biyodizelin 2 nolu Diesel yakıta göre \%13-14 NOx emisyonu verdiğini ifade etmişlerdir [12].

Altın vd., ham ayçiçeği yağı, soya yağı, pamuk yağı ve esterleri, rafine kanola, haşhaş, rafine mısır yağı ve esterlerini 4 zamanlı tek silindir DI dizel motorda testlere tabi tutmuşlardır. Yağ ve esterleri karşılaştırıldığında esterler ile de daha düşük $\mathrm{CO}$ emisyonları elde edilmiştir. Bunun sebebi de daha iyi atomizasyon kalitesi ve daha homojen karışım hazırlanması olarak gösterilmiştir. Bitkisel yağların kullanımı ile dizel yakıta göre NOx emisyonlarında azalma görülürken, esterlerin kullanımı ile dizel yakıta göre daha yüksek NOx emisyonları oluşmuştur. NOx emisyonu maksimum yanma sıcaklığıyla alakalıdır. Bitkisel yağların yanma verimi ve maksimum yanma sıcaklığ 1 daha az ve buna bağlı olarak NOx emisyonları da daha azdır. Fakat bu durum yağların daha fazla is emisyonu oluşturmasına neden olmuştur. Ayrıca yağlardaki daha ağır hidrokarbon molekülleri de is emisyonunun artmasına sebep olmuştur [13].

Tashtoush ve ark. (2004), atık hayvansal yağın etil ve metil estere dönüşümünü ve optimum koşullarını incelemişlerdir. Etanol, metanole göre daha yüksek dönüşüm ve daha düşük viskozite sağlamıştır. Sıcaklık değeri, her ikisinin esterlerinde önemli bir etki yaratmamıştır. Fakat yüksek sıcaklıklarda maksimum dönüşüme ulaşmak için gereken süre kısalmış ve maliyet artmıştır. Yapılan deneyler sonucunda optimum sicaklık $50{ }^{\circ} \mathrm{C}$, optimum süre ise 2 saat olarak elde edilmiştir [14].

\section{Deneysel çalışma}

Yapılan çalışmada ilk aşamada pamuk yağından biyodizel elde edilmiştir. Pamuk yağından biyodizel eldesi için Batman Üniversitesi Mühendislik-Mimarlık Fakültesi Makine Mühendisliği Bölümü Otomotiv Laboratuvarında çalışılmıştır. Pamuk yağından biyodizel eldesindeki aşamalar aşağıda belirtilmiştir. Pamuk yağ 1000 ml'lik beher kaba doldurulup elektrikli 1 sitıcı ile $56^{\circ} \mathrm{C}$ ye ulaşıncaya kadar 1 sıtıld1. $56^{\circ} \mathrm{C}$ seviyesine getirildikten sonra sıcaklık bu derecede sabit tutularak manyetik karıştırıcı ile belirli bir devirde karıştırılarak yağ sıcaklığının her yerde aynı olması amaçlanmıştır.

Isıtılma işlemi sürerken başka bir beherde metil alkol ve $\mathrm{KOH}$ maddeleri karıştırıldı. Kullanılan yağın \%20 oranında metil alkol \%3 oranında da $\mathrm{KOH}$ karıştırıldı. $\mathrm{KOH}$ metil alkol içerisinde tamamen eriyene kadar karıştırıcı ile karıştırıldı. $56^{\circ} \mathrm{C}$ de sabit tutulan pamuk yağının içerisine metil alkol KOH karışımı eklendi ve beherin ağzı folyo ile sıkıştırılıp kapatıldı. Sıcaklığın $56-$ $60{ }^{\circ} \mathrm{C}$ arasında tutulmasının amacı kullanılan metanolün kaynama noktası olan $64^{\circ} \mathrm{C}$ yi aşmasını engellemektir. 1 saat boyunca $56^{\circ} \mathrm{C}$ sıcaklıkta sabit tutularak ve manyetik karıştırıcı ile karıştırma işlemi devam etti.

1 saat süren karıştırma işlemi sonunda karışımın dinlenmesi, gliserinin çökmesi ve 12 saat dinlenme sonunda gözle görünür şekilde iki faz oluşmaktadır. Çöken gliserin uzaklaştırıldı. Elde edilen pamuk yağı biyodizeli içerisinde kalan yağ asitleri, reaksiyona girmeyen alkol, ve katalizör maddenin biyodizelden uzaklaştırmak amacıyla yıkama işımemi yapılması gerekir. 


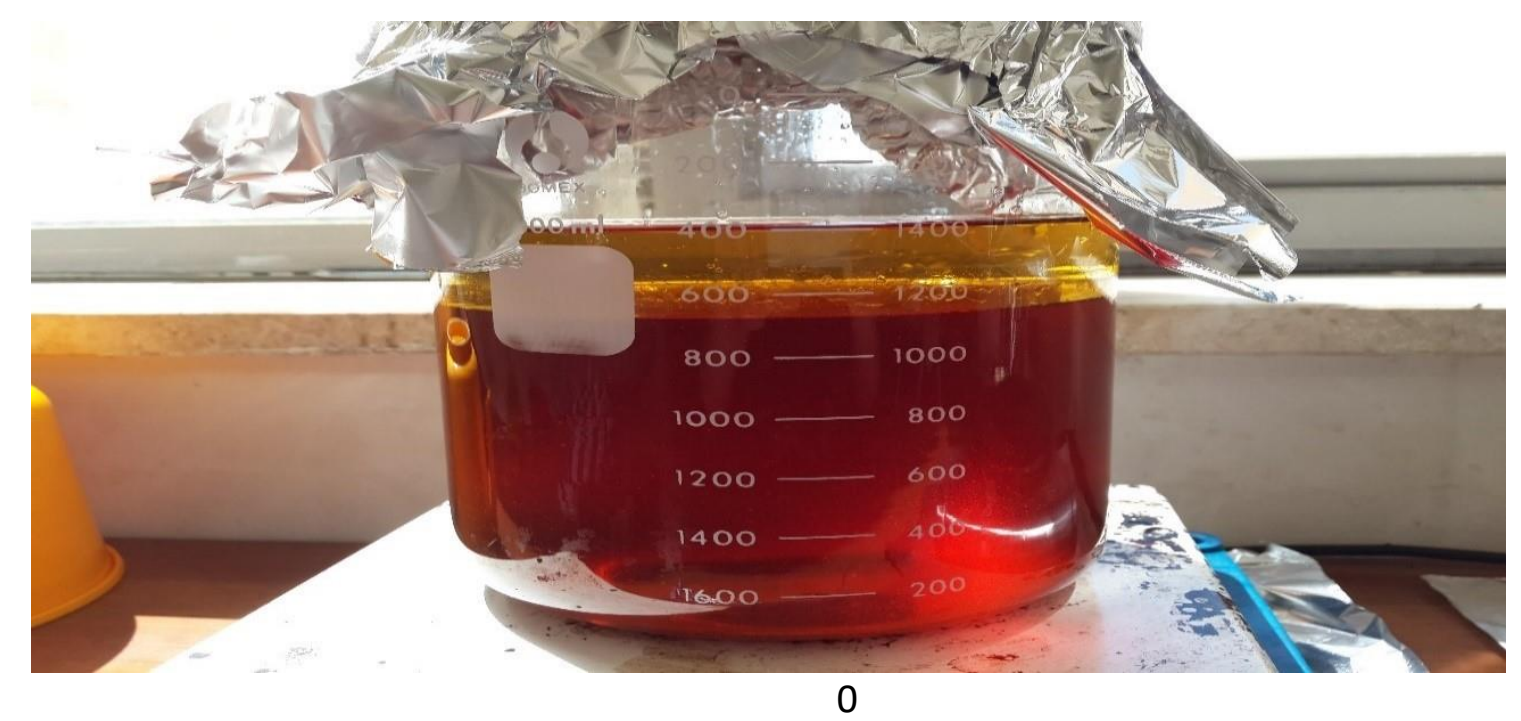

Yıkama işlemi 1 litre biyodizel 1 litre saf su ile karıştırılıp 1sıtılmaya bırakıldı. 1 saat olarak planlanan bu işlemde belirli bir süre sıcaklığın $80-90^{\circ} \mathrm{C}$ de kaldığı gözlemlendi. Sıcaklığın her tarafa yayılması amacıyla manyetik karıştırıcı ile sağlandı. Amaç biyodizelle karıştırılan suyun yüzeye çıkıp buharlaşmasını sağlamak. Bir süre $80-90^{\circ} \mathrm{C}$ de kalan karışım daha sonra $130{ }^{\circ} \mathrm{C}$ seviyelerine ulaşınca işleme son verildi. Biyodizel elde edildi.

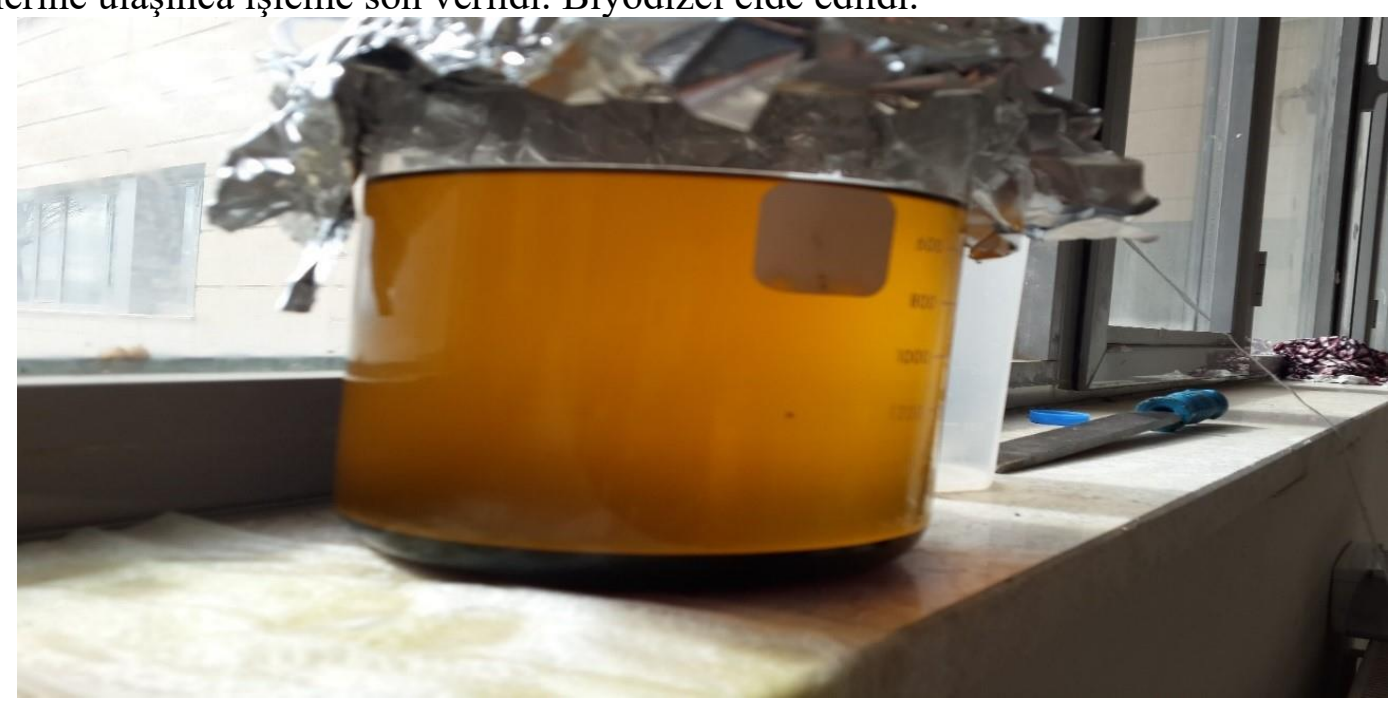

Şekil 2.2. Biyodizel ve gliserinin ayrışması

Elde edilen biyodizel yakıtlar \% 10 ve \% 30 oranında standart dizel yakıta karıștırılmış (B10,B30 ve Atık B10, Atık B30) ve jeneratörde 1500 devirde 0, 3,6, 7,2 ve 10,8 kW yükte yakıtların performans ve emisyon karakteristikleri incelenmiştir. Sonuçlar Saf dizel yakıtla karşılaştırılmıştır. Motorun teknik özellikleri Çizelge 2.1' de verilmiştir. 
Çizelge 2.1 Deney motorunun teknik özellikleri

\begin{tabular}{ll}
\hline Üretici: & NWK22 \\
\hline Güç çıkışı: & $1500 \mathrm{rpm} \mathrm{18} \mathrm{kW}$ \\
\hline Motor Soğutma Sistemi: Su soğutma & \\
\hline Emme Sistemi: & Doğal aspire \\
\hline Motor modeli: & 4 DW81-23D \\
\hline Çap x strok: & $85 \times 100$ (mm) \\
\hline Hacim: & 2400 cc \\
\hline Silindir sayısı: & 4 \\
\hline Yanma sistemi: Doğrudan enjeksiyonlu \\
\hline Sıkıştırma oranı: & $17: 1$ \\
\hline
\end{tabular}

Deneylerde egzoz emisyon ölçümleri için CAPELEC CAP 3200 marka egzoz emisyon cihazı ile kullanılmıştır. Çizelge 2.2.' de teknik özellikleri verilmiştir.

Çizelge 2.2. Deney motorunun teknik özellikleri

\begin{tabular}{|l|l|l|}
\hline EMISYON & ÖLÇÜM ARALIĞI & HASSASIYET \\
\hline $\mathrm{HC}$ & $0-20,000 \mathrm{ppm}$ & $1 \mathrm{ppm}$ \\
\hline $\mathrm{CO}_{2}$ & $\% 0-20$ & $\% 0.1$ \\
\hline $\mathrm{CO}$ & $\% 0-15$ & $\% 0.001$ \\
\hline $\mathrm{O}_{2}$ & $\% 0-21.7$ & $\% 0.01$ \\
\hline $\mathrm{NO} x$ & $0-5000 \mathrm{ppm}$ & $1 \mathrm{ppm}$ \\
\hline Duman koyuluğu & $\% 0-99.9$ & $\% 0.01$ \\
\hline
\end{tabular}




\section{Sonuçlar}

\section{1. ÖYT}

Herhangi bir güçteki çalışma sırasında bir saatte tüketilen yakıt miktarının üretilen güce oranına denir. Özgül yakıt tüketimi değerleri biyodizelin dizel yakıta göre artış göstermesinin sebebi 1sıl değerinin daha düşük olmasıdır.

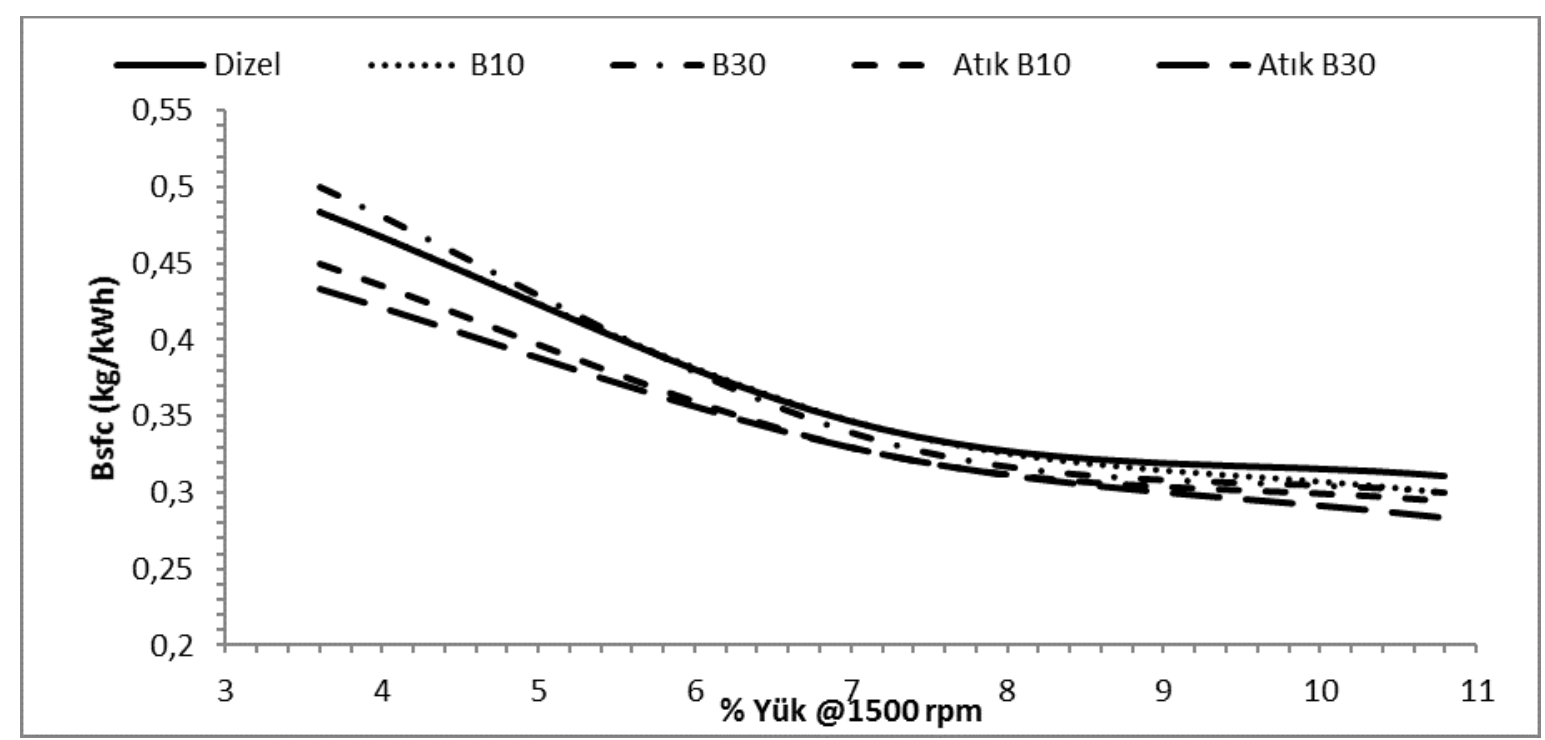

Şekil 3.1. Özgül yakıt tüketimi

\subsection{Termal Verim}

Şekil 3.2' den gözlemlenecek olursa atık pamuk yağ biyodizeli ve pamuk yağı biyodizel yakıtlarının özellikle yüksek yüklerde termal verim değerlerinin dizel yakıtına göre daha yüksek olduğu görülmüştür. Yanmanın daha verimli olarak gerçekleştiği anlamına gelmektedir. 


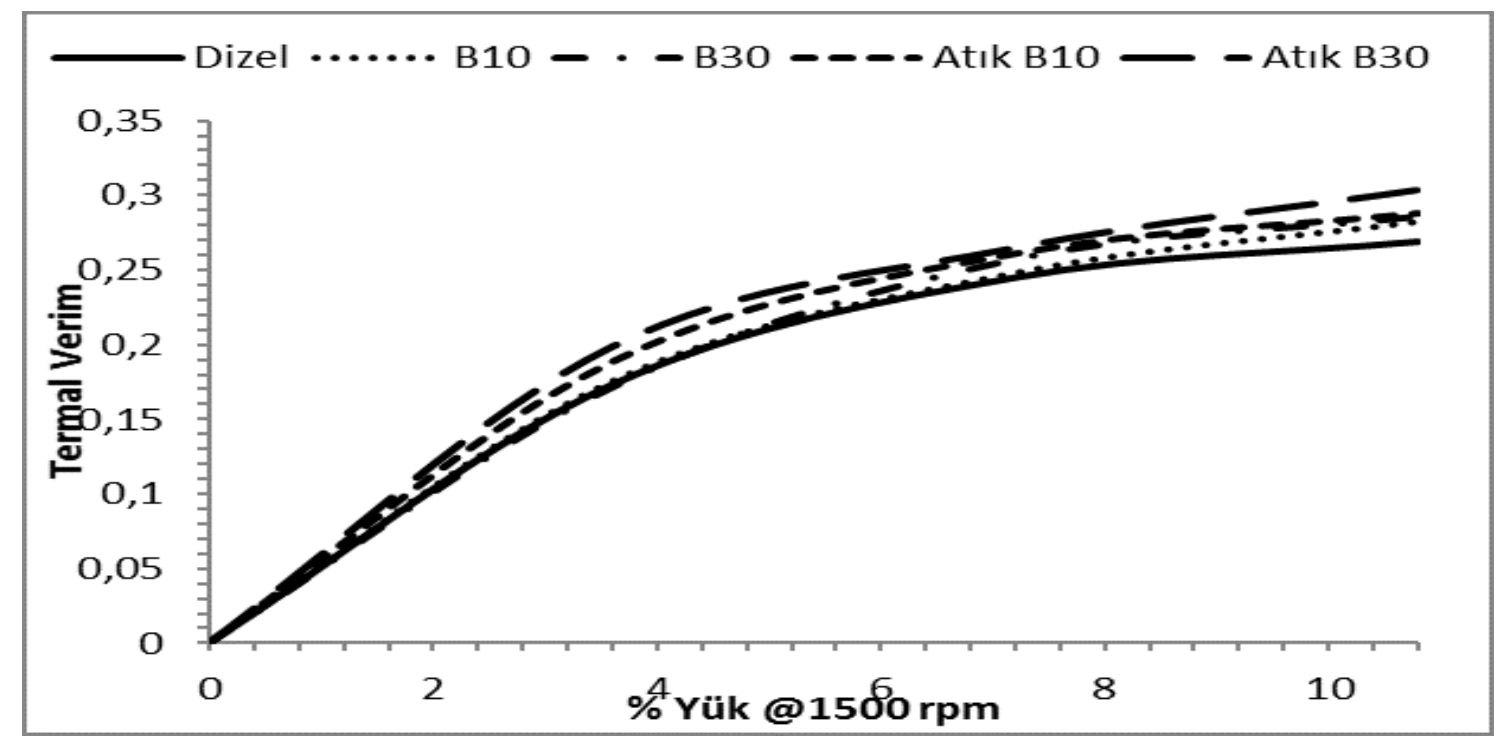

Şekil 3.2. Termal verimin değerlendirilmesi

\subsection{Egzoz sıcaklığı değgerlendirilmesi}

Test yakıtları karşılaştırıldığında egzoz gazı sıcaklığı biyodizel yakıtların egzoz gazı sıcaklığının daha yüksek olduğu görülmektedir. Yanmanın geç safhalarında sıcaklığın yüksek seyrettiği anlamına gelmektedir.

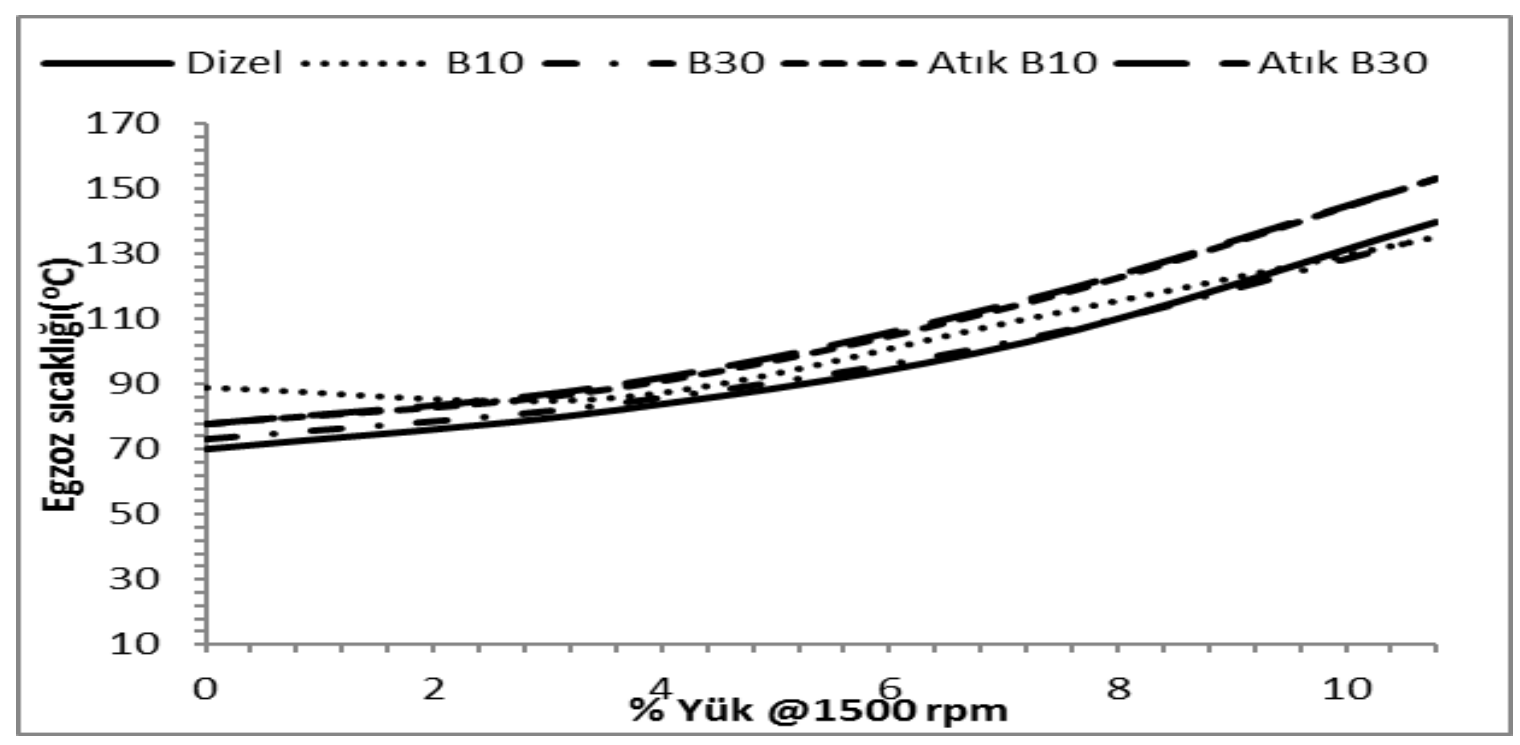

Şekil 3.3. Egoz sıcaklığının değerlendirilmesi

\subsection{CO emisyonu}

Yük arttıkça CO değerlerinde genel bir azalma söz konusudur. Özellikle dizel eğrisinde daha belirgindir. Diğer yakıtlarda $3.6 \mathrm{~kW}$ yük bölgesindeki değerinin yüksek kalması farklılaşmasına 
neden olmuştur. Eğrilerin motorun sıcaklığının artmasıyla beraber yanmanın iyileşmesi CO emisyonunu azaltmıştır. Biyodizel yakıtların genel anlamda CO emisyonları daha yüksek seyretmiştir. Bu olumsuz bir parametre olarak görülebilir. Ancak genel olarak $\mathrm{CO}$ emisyonu tüm yakıtlar için \%0.04 değerinde olması istenilen değerlerdedir.

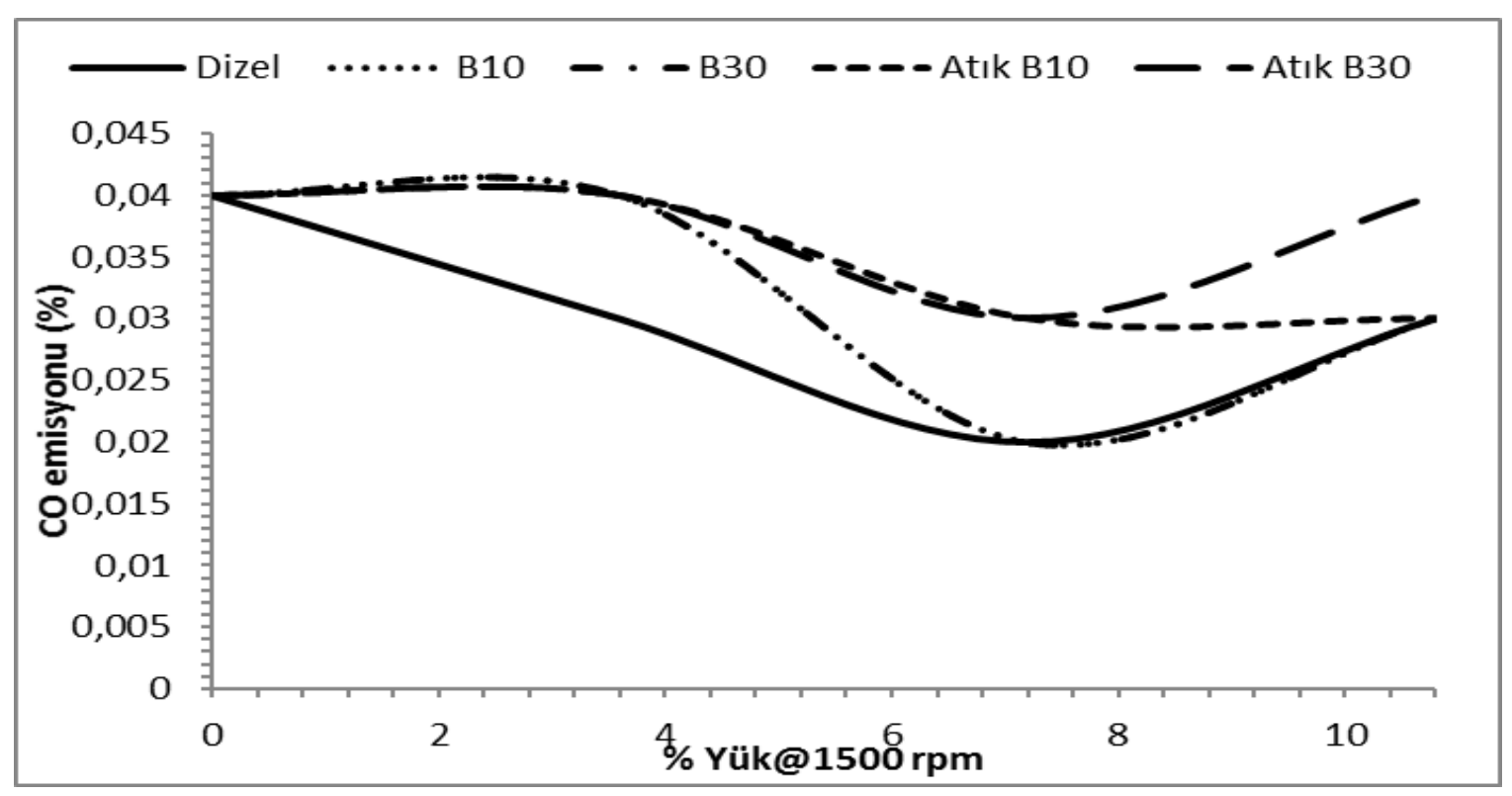

Şekil 3.4. CO emisyon değerleri

\subsection{CO emisyonu}

Tüm yakıtlar için $\mathrm{CO}_{2}$ emisyonunun yüke bağlı artış gösterdiği gözlemleniyor. $\mathrm{CO}_{2}$ emisyonunun artması tam yanma ürünü olan $\mathrm{CO}_{2}$ emisyonun artması yanmanın iyileştiği anlamına gelmektedir. Yakıtları karşılaştırdığımızda biyodizel yakıtlarının yanma verimlerinin yüksek olmasından dolayı özellikle orta ve yüksek yüklerde $\mathrm{CO}_{2}$ emisyonu dizel yakıtına göre daha yüksek olmuştur. 


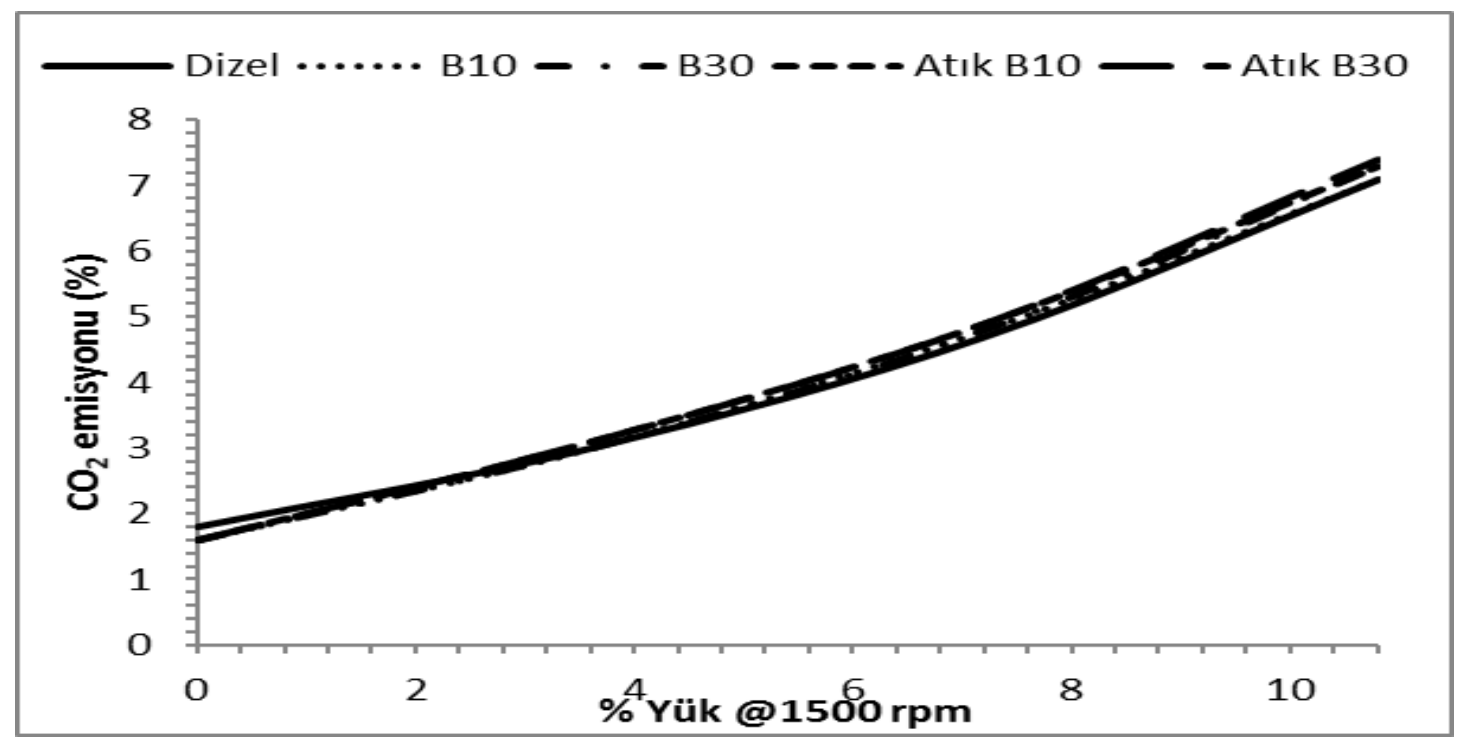

Şekil 3.5. $\mathrm{CO}_{2}$ emisyon değerleri

\subsection{HC emisyonu}

Motor yükü arttıkça yüksek yüklerde HC emisyonlarının biyodizel yakıtları için daha düşük seyretmesi karışım biyodizel yakıtları için yanmanın daha iyi olduğu anlamına gelmektedir. $\mathrm{Bu}$ değerler benzinli motorlara göre oldukça düşük değerlerdir. Dolayısıyla HC emisyon değerleri tüm yakıtlar için düşük seyretmiştir. Yüklü durumlarda biyodizel yakıtları için HC emisyonları dizel yakıtına göre daha düşük seyretmesi bu durumun biyodizelin yanma verimin yüksek olmasını sağlamıştır.

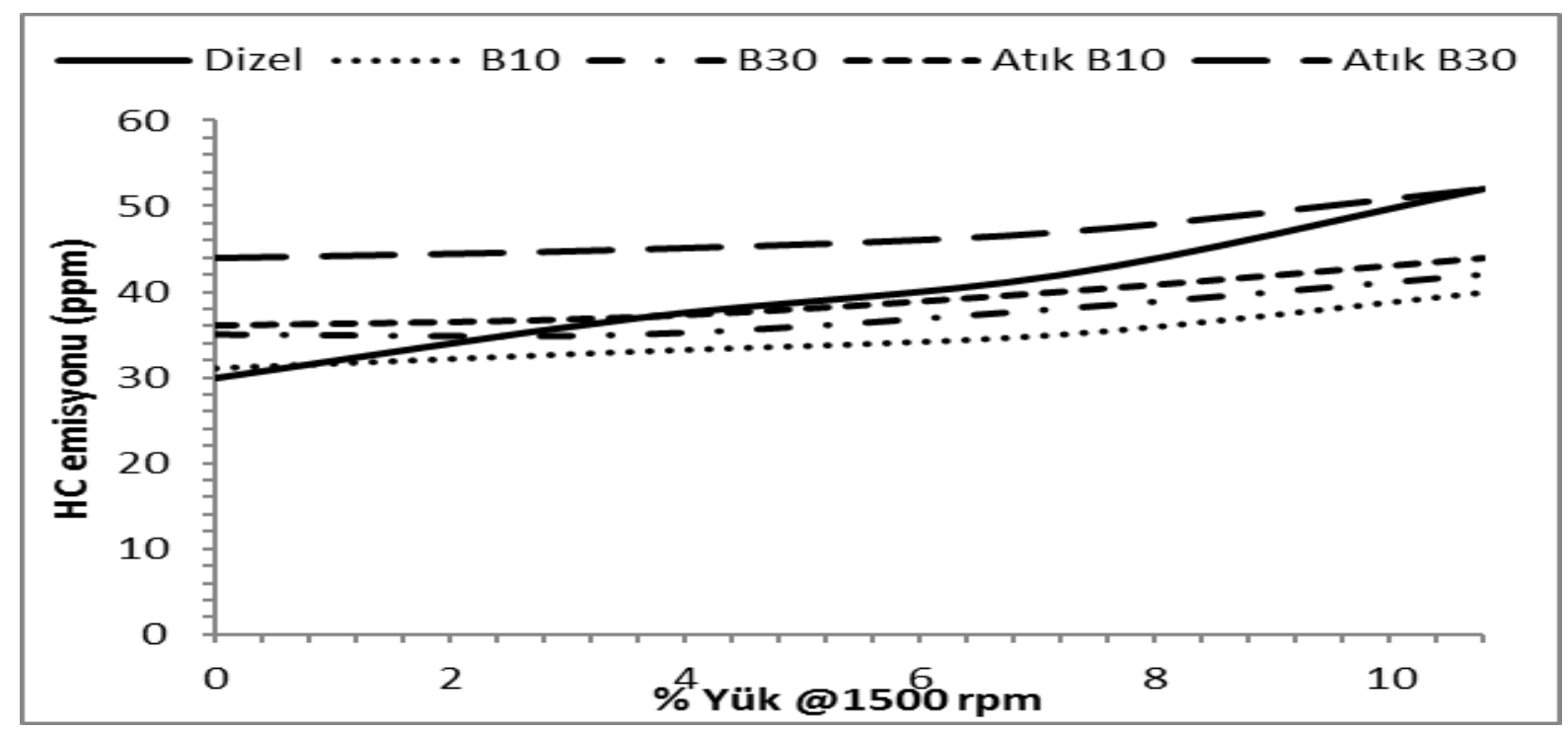

Şekil 3.6. HC emisyon değerleri 


\section{7. $\mathrm{NO}_{X}$ emisyonu}

Literatürdeki bilgiler 1şığında değerlendirildiğinde NOx emisyonlarının dizel motorları için yüksek olduğu gözlemlenmektedir. Yüksek sıcaklıklarda $+1800^{\circ} \mathrm{K}$ yüksek sıcaklıklarda azotun hava ile reaksiyona girmesi sonucu NOx emisyonları oluşuyor. Yük arttıkça sıcaklık arttığından tüm test yakıtları için NOx emisyon değerleri artmıştır. Biyodizel yakıtları ile dizel yakıtı karşılaştırıldığında biyodizel yakıtlarının NOx emisyonu dizel yakıtına göre daha düşük seyretmiştir.

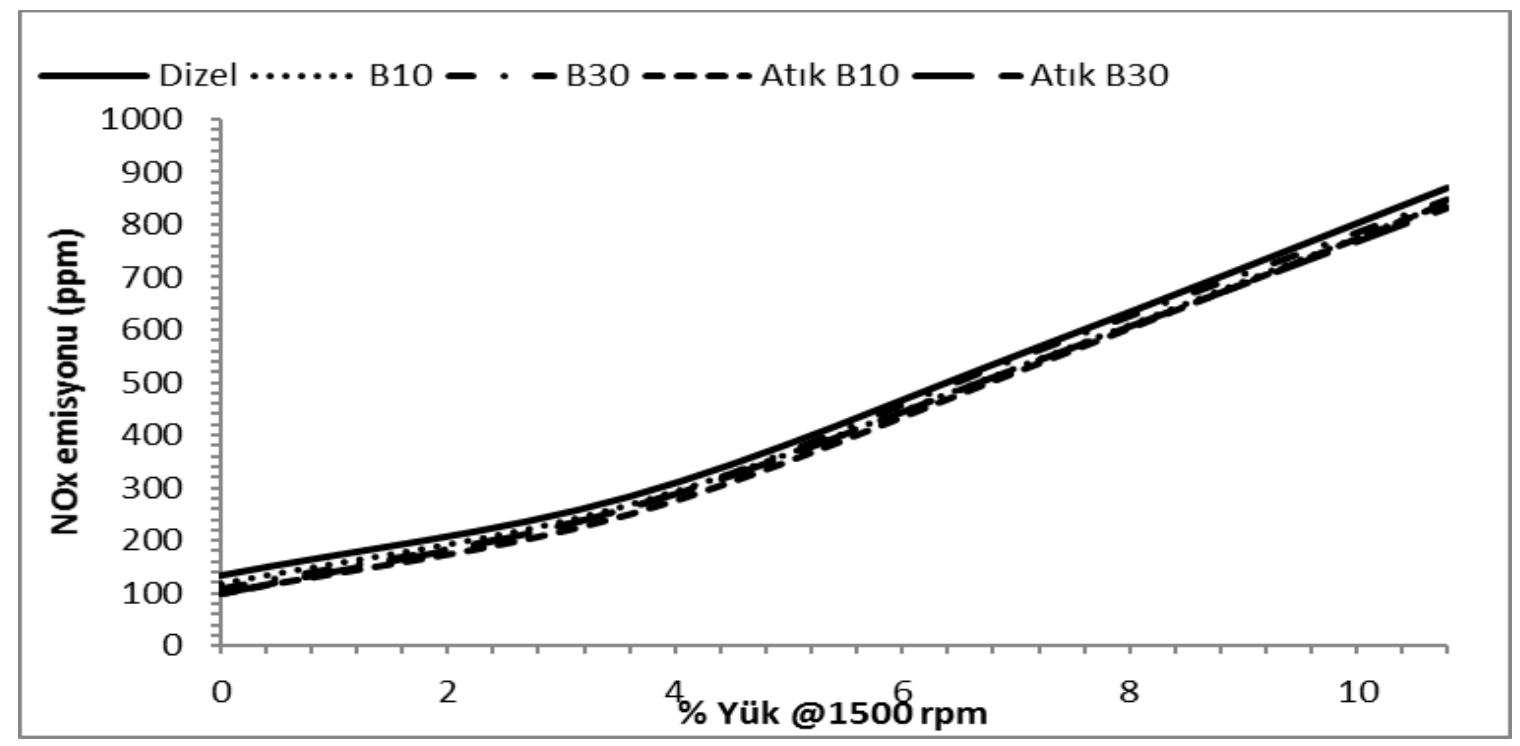

Şekil 3.7. $\mathrm{NO}_{\mathrm{x}}$ emisyon değerleri

\section{Sonuç}

$\mathrm{Bu}$ çalışmada pamuk yağının normal ve atık hallerinden elde edilen biyodizelin dizel yakıt ile belirli oranlarda karıştırılarak motor üzerindeki yanma, performans ve emisyon sonuçları gözlemlenmiştir.

Motor testleri incelendiğinde; yanma deneylerinde silindir basınc1, 1S1 salınım hızı, toplam 1S1 salınımı, ortalama gaz sıcaklığı ve kütlesel yanma parametrelerinde yükün artmasıyla birlikte biyodizel yakıtların dizel yakıtlara benzer özellikler göstermiştir.

Performans sonuçlarında kütlesel yakıt tüketiminin dizel yakıtların biyodizel karışımı yakıtlarına göre düşük olmuştur. Ancak termal verim ve egzoz gazı sıcaklıkları incelendiğinde biyodizel karışım yakıtlarının termal verimleri ve egzoz gazı sıcaklıkları daha yüksek seyrettiği gözlemlenmiştir.

Yakıtların emisyon sonuçları incelendiğinde CO emisyon değerleri biyodizel karışımı yakıtların daha yüksek değerde seyretmiştir bu durum olumsuz bir parametre olarak gösterilebilir. Ama $\% 0.04$ istenilen sinırlar içerisindedir. Tüm yakıtlar için $\mathrm{CO}_{2}$ emisyonu yüke bağlı olarak 
artmaktadır. HC emisyonlarında motor yükü arttıkça biyodizel karışım yakıtları için daha düşük seyretmesi bu durum yanmanın daha iyi olduğu anlamına gelmektedir. NOx emisyonlarında biyodizel karışımı yakıtlarının dizel yakıtlarına göre düşük seyrettiği gözlemlenmiştir.

Sonuç olarak biyodizelin dizel yakıt ile belirli oranlarda karıştırılarak kullanılabileceği hakkında önemli fikirler vermektedir. 


\section{Kaynaklar}

[1]Usta, N., Can, Ö., Öztürk, E., “Alternatif Dizel Motor Yakıtı Olarak Biyodizel ve Etanolün Karşılaştırılması", Pamukkale Üniversitesi Mühendislik Fakültesi Mühendislik Bilimleri Dergisi, 11(3): 325-334, 2005.

[2] Cang1, A.A., 2007, 7. Ulusal çevre müh. kongresi, yaşam çevre teknoloji, Ekim 2007, İzmir.

[3]Johansson, T., McCarthy, S., 1999, Global warming post-Kyoto: continuing impasse or prospects for progress? Energy DevRep Energy 1999:69-71.

[4] Ulusoy Y., Alıbaş B., 2002, Dizel Motorlarda Biyodizel Kullanımının Teknik Ve Ekonamik Olarak İncelenmesi Uludağ Üniversitesi ZiraatFakültesi Dergisi, 2002 16: 37-50.

[5] İlkılıç, H., Yücesu, S., 2002, Değiş̧ik enjeksiyon basınçlarında ayçiçeğiyağı metil esteri ile dizel yakıtı karışımının dizel motoru egsoz emisyonlarına etkisinin incelenmesi, 7. Uluslar arası yanma sempozyumu, temmuz 2002, Ankara.

[6] Alptekin, E. ve Çanakcı, M., 2008, Farklı Hammaddelerden Üretilen Metil Ester ve Gliserinin Bazı Özelliklerinin Belirlenmesi, Gazi Üniv. Müh. Mim.Fak. Der., 23(3), 549-556ss.

[7] Fukuda, H., Kondo A. and Noda H., 2001, Biodiesel Fuel Production by Transesterification of ois, Journal of Bioscience and Bioenginnering, 92: 405-416pp.

[8] Yücesu H.S., Altın R., Çetinkaya S. "Dizel motorlarında Alternatif Yakıt Olarak Bitkisel Yăg Kullanımının Deneysel İncelenmesi” Turkısh Journal of EngineeringEnvironmental Sciences. Vol 25 3949,2001

[9] Çelik, M., 2005, Biyodizel Üretiminde Yıkama Prosesinin Yakıt Özelliklerine Etkisi, Yüksek Lisans Tezi, Selçuk Üniversitesi Fen Bilimleri Enstitüsü

[10] Karabektaş, M., Ergen, G., "Taşıtlarda doğalgaz kullanım teknolojileri” 5. Uluslararası İleri Teknolojiler Sempozyumu (IATS’09), Karabük, 1-6 (2009).

[11] Agarwal, A., K. "Biofuels (Alcohols And Biodiesel) Applications As Fuels For Internal Combustion Engines", Progress In Energy And Combustion Science ,vol.33, pp.233-271, 2007.

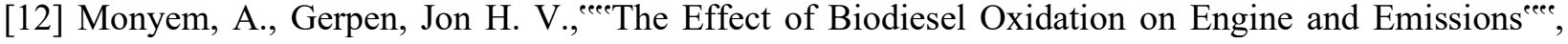
Biomass and Bioenergy, 20: 317-325, 2001.

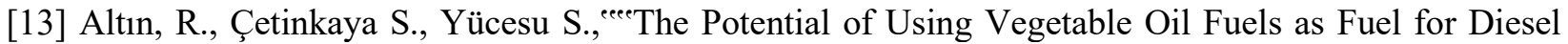
Engines $^{\text {eeee }}$, Energy Conversion and Management, 42: 529-538, 2000.

[14] Tashtoush, M.G., Al-Widyan, M.I. and Al-Jarrah M.M., 2004, Experimental study on eveluation and optimization of conversion of waste animal fat into biodiesel, Energy Conversion and Management, 45: 2697-2711pp. 